\title{
Care-focused Feminism, Care Ethics, and Feminine Artistry in Willa Cather's The Professor's House
}

\author{
Hyojeong Byun \\ Associate Professor, College of Creative Future Talent, Daejin University, Pocheon-si, \\ South Korea. ORCID: oooo-0oo2-4850-0843. Email: byunglish@daejin.ac.kr
}

\begin{abstract}
Willa Cather's The Professor's House dismantles feminine behaviors, as Cather ascribes new meaning to her marginalized female characters' independent acts and depicts male characters being saved by women. Cather's care and care ethics are based on human relations; they highlight empathy, responsibility, acceptance, and emotion-based practice. She accordingly shows sincere care and acts in the spirit of salvation for the characters' surroundings, culture, and society through marginalized figures such as Augusta, Mother Eve, and Tom. These are examples of alternative caregivers who develop a connectionbased relationship through their sincerity and attentiveness and cultural and social care. In their care, we observe a spirit of self-sacrifice and the possibility of a true bond between them and others and their communities. This article conveys Cather's capacity for serving as a conduit for healing and solidarity and proves her visionary force of care practice.
\end{abstract}

Keywords: Willa Cather, The Professor's House, care, care ethics, care practice.

\section{Introduction}

Today, feminism has considerable theoretical value due to its implementation of a wide variety of concepts and analysis methods. Acknowledging the diversity of women's experiences, it emphasizes women's value and active power to resist sexual, political, social, religious, cultural, and emotional discrimination multilaterally, under the directive of seeking women's freedom and liberation. Care-focused feminism is a theory that fits within the current sociocultural landscape (which can be called the era of disaster of COVID-19; an era in which the role of women's care is emphasized, both in society and at home), as it highlights the broad meaning of women's attentiveness in caring for others. Under the assumption that women's care values and sacrifices are being disparaged by a male-centered social system and its accompanying discourse, in her 1925 novel, The Professor's House, Willa Cather underscores the importance of the feminist and feminine power of sacrifice, consideration, labor power, connectivity, and its positive effect on society.

According to Nel Noddings, a theorist of care ethics, "a caring relation is ethically (morally) basic" (2012, p. 771). Therefore, care ethics, as a universal human concept, is based on human responsibility and cooperation, acceptance and support, and empathy and understanding. In particular, Noddings, who developed a woman-centered ethics based on human relations, highlights the importance of relational ethics, focusing on reciprocity and human-centered care. Noddings' care ethics challenges the male-centered biased gaze and aims to elevate women's value without subjecting it to prejudice and subordination. Further, according to Peta Bowden, "Caring expresses ethically significant ways in which we matter to each other, transforming interpersonal relatedness into something beyond ontological necessity or brute survival" (1997, p. 1). Moreover, as care can be internalized through habits and training,

(c) AesthetixMS 2021. This Open Access article is published under a Creative Commons Attribution Non-Commercial 4.o International License (http://creativecommons.org/licenses/by-nc/4.o/), which permits non-commercial re-use, distribution, and reproduction in any medium, provided the original work is properly cited. For citation use the DOI.

For commercial re-use, please contact editor@rupkatha.com. 
and can become part of one's personality, Joan Tronto notes that care ethics of a moral ideal is "the highest social goal" (1993, p. 175), while Sara Ruddick emphasizes that "the reciprocal play of memory and identity" (1998, p. 21) can be related to care ethics. This means that humans can be open to the possibility of truly uniting with their communities through warm memories of care when forming their identity. All of these elements together result in ideal and reciprocal care, where individuals' willingness to act stands out, as care cannot be expected or provided forcibly. Therefore, the practice of care ethics can enhance individuals' spontaneous will, make them truly happy members of society, and lead them to well-being beyond the logic of exploitation and domination that is prevalent in our societies.

Cather's novel The Professor's House has a "symbolic expression than her other stories" (Lewis, 2000, p. 137) and a "narrative seeking equilibrium" (Rosowski, 2003, p. 116). Above all, it alerts its readers to a male-centered patriarchal society marked by materialism, giving them a wide perspective of the various obligations individuals should observe when interacting with each other. Since its publication, the novel has mainly been analyzed for the way it portrays the search for the cause of its protagonist's lethargy, but other elements have also been discussed, including Cather's view against materialism, the novel's queer characteristics, and ecological elements. In particular, the novel dismantles socially constructed feminine behaviors, as Cather ascribes new meaning to her marginalized female characters' independent acts and depicts male characters being saved by women (who act as good natural agents).

By analyzing The Professor's House, this essay will explore how Cather's female and feminized characters practice their own care ethics as caregivers, find a balance in their community and in society, and restore their relationship with their surroundings. Furthermore, by discussing the social and aesthetic values of feminine care through the way Cather depicts women, this essay complements previous research that analyzed from the protagonist's viewpoint and will provide moral indicators that can be a modern alternative to the marginalized women's care.

Care, which has been described as "the heart of human existence" (Engster, 2007, p. 1), has the unique power of serving as a conduit for healing and solidarity. Therefore, this essay aims to illuminate the meaning of feminine sincere care, care ethics, community values, and healthy socialization of care. To elaborate further, it seeks to explore the feelings of love, empathy, consideration, sympathy, attentiveness, and solidarity as they are expressed through care. Lastly, it shows that care practice and care ethics performed by women can be a healing and visionary force in modern society, particularly in the current era of disaster.

\section{St. Peter's Ideal, or the Unfaithful Female Figure}

In the early twentieth century, with the advent of the $19^{\text {th }}$ Amendment to the United States Constitution and the rise of the women's movement, men's social power over women began to wane. In 1920, women obtained the right to vote in the United States; however, women did not have the right to vote for much of Cather's lifetime. In this context, the protagonist of Cather's novel, professor Godfrey St. Peter, wants to keep his authority over his hyper-feminized family and wishes stay at his old house, which is a testament to his honor and brilliant personal history. Jessica G. Rabin argues that St. Peter "wants to control his surroundings and the 'women' in his life to maintain a past that is no longer viable" (2004, p. 57). In fact, St. Peter, along with his wife Lillian, in his youth, showed an ideal family bond by performing their parental duties and had a keen interest in raising children. Now, however, he is struggling to find his real self amid various fluctuating roles and requirements. For this reason, rather than taking care of his family in the new house where they live, St. Peter-as a feeble husband and father and a daydreamerwishes to revive his former glory "amidst the spiritual desert of his social life" (Durrans, 2010, p. 178). He remains secluded in his attic study; yet, he feels like the head of the household at all 
times. In this regard, feminist critics have noted the masculine privilege embedded in St. Peter's character.

The only realistic care that St. Peter acknowledges is provided by his seamstress, Augusta, who is a rather androgynous-looking sewing woman. Augusta is the niece of the old landlord; as St. Peter's caregiver, she is the one who ultimately integrates his divided world. Augusta "moves up and down the stairs between the high and low spheres of the novel easily and regularly" (Baker, 2010, p. 264). She focuses on taking care of Peter's mind, spirit, and body. Here, the most important thing is that Augusta's care is not a task but a matter of responsibility and a display of attentiveness. Further, a deep concern for his mind drives Augusta's care. Considering that Augusta is the first person to be mentioned in the novel after St. Peter, one can easily see how important her role in caring is. She is physically sturdy, unlike St. Peter's two feminine daughters, Rosamond and Kathleen; therefore, she has the required physicality to provide focused care for him. Furthermore, as part of women's liberation, Cather depicts Augusta as an unmarried woman. From the perspective of radical feminists, as they emphasize "the dangers of sex, especially heterosexual sex" (Tong, 2018, p. 2), she is an authentic caregiver who acts as an independent being outside the category of heterosexual love. Yet, St. Peter-who closely observes Augusta's physical characteristics-remains ensnared by his own preconceived ideas, trying to judge her superficially, instead of treating her as an equal:

He had often wondered how she managed to sew with hands that folded and unfolded as rigidly as umbrellas - no light French touch about Augusta; when she sewed on a bow, it stayed there. She herself was tall, large-boned, flat, and stiff, with a plain, solid face, and brown eyes not destitute of fun. As she knelt by the couch, sorting her patterns, he stood beside her, his hand on the lid, though it would have remained unsupported. (Cather, 1990, p. 14)

Additionally, Augusta has to face St. Peter's quips about her graying hair, her apparent asexuality, and her aging body, all of which she shrugs off with a smirk. Yet, she is the only one who can see his real feelings. St. Peter's behavior is not harmful, as his desire is not actually likely to be projected toward her. Above all, her actions can be seen as a victory of care, as she helps him recover his vitality in the end. Considering that she is a seamstress, her role is to sew St. Peter's mind back together. Furthermore, in performing various domestic tasks (such as sewing and organizing), she advises St. Peter directly. This way, the professor eventually foregoes his responsibility toward his family in an effort to become a whole person with the help of Augusta, who reminds him of his glory days. In this sense, Augusta, is a "unifying figure" (Baker, 2010, p. 264) as she also plays a maternal role through her emotional interaction with St. Peter by showing him a combination of expert care and empathy. Thus, Augusta is an example of an alternative female caregiver who develops a connection-based relationship:

When she sewed for them, she broke out at the house, which was part of the arrangement. She came early, often directly from church, and had her breakfast with the professor before the rest of the family were up. Very often, she gave him some wise observation or discreet comment to begin the day with. (Cather, 1990, p. 255)

Care-focused feminism assigns special value to care ethics, highlighting that humans are dependent creatures who must exchange care with each other and foster one another's moral strengths. In light of this, Augusta's care (along with other values, such as altruism, compassion, sincerity, and empathy) is so special that St. Peter associates her with the powers of nature by saying that "Augusta was like the taste of bitter herbs" (Cather, 1990, p. 256). This shows that her care, like a mother's breast, is innocent and understanding.

St. Peter's study is linked to death, in that it evokes a cellar, a grave, or a coffin, even though it is located on the third floor of the house. St. Peter's old house is "a gothic wreck" 
(Moseley, 2002, p. 64), where he dreams of a patriarchal system, which gives him some sense of comfort, even when he is unable to save himself; however, he has no power to save himself. Here, he is entirely dependent on others. Despite this reality, he is frustrated to hear that all of his family members have come back from their trip to Europe. Hoping he would never wake, St. Peter falls asleep with the gas stove on, putting himself at risk of asphyxiation. Fortunately, Augusta saves him from dying in his study. When he wakes up, Augusta says to him, "I was barely in time to pull you out," to which the professor answers, "You pulled me out, literally? Where to?" (Cather, 1990, p. 253). St. Peter, whose life was saved by Augusta, now truly embraces her, as he recognizes the value of her care: "Augusta, he reflected, had always been a corrective, a remedial influence" (Cather, 1990, p. 255). According to Gilbert and Gubar, Augusta (herself a solitary and spiritual creator with emotional concern for others) seems to represent "an archaic, almost mystical, female wisdom" (1989, p. 210). Furthermore, Augusta's actions remind the reader of the true meaning of care: helping others grow. Cather also tells us that St. Peter feels "a world full of Augustas, with whom one was outward bound" (Cather, 1990, p. 257), as well as "the ground under his feet" (Cather, 1990, p. 258).

Furthermore, in the novel, Tom Outland discovers the mummified remains of a woman-who comes to be known as Mother Eve-in Cliff City, Blue Mesa during the excavation of ancient artifacts. Usually, she is represented as an example of Eros, a feminine spirit, meeting Logos, a masculine spirit. Mother Eve is, as the name suggests, the mother of humankind; she represents female power and sexuality. However, contrary to her hallowed name, the discovered remains tell a tale of violence so terrible that the onlookers at the dig site begin to wonder about the circumstances of her death:

We thought she had been murdered; there was a great wound on her side, and the ribs struck out through the dried flesh. Her mouth was open as if she were screaming, and her face, through all those years, had kept a look of terrible agony. Part of the nose was gone, but she had plenty of teeth, not one missing, and a great deal of coarse black hair. Her teeth were even and white, and so little worn that we thought she had been a young woman. (Cather, 1990, p. 192)

The dead body conveys a message to Tom's party. Her horrific death seems to be "crying out against the injustices of gender" (Perriman, 2006, p. 247). Perhaps Mother Eve is a symbol for female martyrdom, as she was likely forced to remain silent regarding the injustices of the malecentered society of her day. Therefore, Cather's intention could be to condemn toxic masculinity: "Even in supposedly advanced patriarchal societies it is common to find females blamed as the source of sin" (Perriman, 2006, p. 247). In addition, Henry, who is part of Tom's excavation team, is the one who names the dead woman Mother Eve. As an orphan, Henry may have projected his longing for his absent mother and her care unto Mother Eve, leading us to speculate that she may have played a role as a mother during her life. However, she is now represented as a woman who is disqualified from taking care of her surroundings. In addition, Father Duchene simply assumes that Mother Eve was killed by her husband for cheating on him with a young man. Although Cliff City is a feminist place called the Eagle's Nest (a symbol for nurturing femininity), a tower (a symbol for phallic masculinity) is built in the center, suggesting that her sacrifice occurred as a result of the male ruling culture. In other words, regardless of the motive, it is logical to assume that men perpetrated her death. Her remains are enough to prove that she was a scapegoat of male violence to boost moral motivation among visitors. In this respect, "Mother Eve (significantly named) represents the marginalized, abused, and misunderstood in an apparently integrated ancient culture" (Peek, 2010, p. 10).

In The Professor's House, Cather firmly roots Augusta and Mother Eve within their own interior space, successfully proving that without female care and ethical responsibility, it is impossible to correct injustice, unfairness, and alienation. Thus, female care and ethical responsibility are paramount to restoring society and humankind. 
Care-focused Feminism, Care Ethics, and Feminine Artistry in Willa Cather's The

Professor's House

\section{Tom's Feminist Care and Feminine Artistry}

St. Peter's sole subject of voluntary care is Tom, who exists only in characters' stories and memories. The character of Tom is "a vehicle for Cather's idealism" (Kot, 2002, p. 395). By practicing his care by annotating Tom's diary, "St. Peter attempts to revive Tom as part of the cultural heritage by publishing his Cliff City diary" (Kot, 2002, p. 418). Tom, as a key figure, makes St. Peter feel like "he has lost everything, whereas Tom wakened with the feeling that... [he] had found everything" (Peek, 2010, p. 10). In the novel, Tom shows that practical social care can be a male role, by serving as a guardian and by finally completing his own feminine artistry. This is related to the characteristics of truly embracing the community and society and fulfilling one's responsibilities based on freedom and sincerity.

Tom has an adventurous spirit; he accidentally found archeological artifacts and an ancient dwelling in when he was a cowboy. Topographically, the area is in the shape of a "V," evoking a female image. Tom therefore feminizes the landscape, describing curved bodies of water and highlighting nature's romantic allure. Above all, Cather notes that Cliff City is a good way to bring care ethics to mind, in the sense that a human being sets a standard for universal ethics through practice with sincere human concerns that will contribute to humanity. Therefore, it is where "humanity . . lifted itself out of mere brutality" (Cather, 1990, p. 199). Further, Cliff City serves as a home for decent people, as it is "an ideal image of communal life" (Leddy, 1996, p. 189). In particular, the cliff dwellers' care is reflected in their artifacts and architecture. A considerable number of artworks symbolize peace, while their designs have high aesthetic, artistic, and historical value. In addition, their architecture is designed to maintain "absolutely harmonious with its site and setting" (Kot, 2002, p. 399). Josephine Donovan mentions the artistry of Cliff City "as evidence of an aesthetic of care" (2016, p. 62). For this reason, "Tom's own plan had been to see them [the artifacts] ensconced in a museum" (Baker, 2010, p. 256) to wholly honor their spirit and value. At this point, Tom, who practices voluntary care for himself, is clearly different from St. Peter or Louie Marcellus, who represent the "privileged irresponsibility" (Tronto, 1993, p. 121) of patriarchy and capitalism, the sources of women's oppression. Furthermore, “Tom is a would-be 'custodian' of [his] national heritage" (Kot, 2002, p. 415). Therefore, one day Tom visits officials in charge of the Indian Commission of the Central Government in Washington, DC to donate countless artifacts to the US government, so they may be preserved. However, the officials consider the Blue Mesa relics to be insignificant, at one point even using one of the artifacts as an ashtray. Tom is forced to buy the secretarial staff lunch to convince them to comply with his request:

At last, the Commissioner returned, but he had pressing engagements, and I hung around several days more before he would see me. After questioning me for about half an hour, he told me that his business was with living Indians, not dead ones, and his office should have informed me of that in the beginning. He advised me to go back to our Congressman and get a letter to the Smithsonian Institution. I packed up my pottery and got out of the place, feeling pretty sore. The head clerk followed me down the corridor and asked me what I'd take for that little bowl he'd taken a fancy to. He said it had no market value, I'd find Washington full of such things. (Cather, 1990, p. 204)

Cather's art pursues "a search for something for which there is no market demand ... where the values are intrinsic and have nothing to do with standardized values" (Cather, 1988, p. 103). In this search, Cather displays some similarities to her character, Tom, who tried to preserve priceless artifacts but now felt defeated. Tom remarked feeling lonesome before leaving Washington. Tom also refers to Cliff City as our city; his inclusive spirit of care is filled with human concern, sincere responsibility, and aspiration for the socialization of care. By transforming "material ownership and personal ambition into 'beautiful beliefs,' he experiences them as acts of sacrifice and humility, resonant with the sense of 'filial piety' he reads in 'the 
Latin poets"' (Wagers, 2015, p. 109). After his failure, Tom visits the mesa again and spends a solitary summer there concentrating on the Æneid. As he reads the book, he can see two pictures in his mind all the time: "a rude tower rising in their midst, rising strong, with calmness and courage-behind it a dark grotto, in its depths a crystal spring" (Cather, 1990, p. 228). Here, the grotto represents the vaginal opening, a representation of femininity. In other words, Tom redefines the meaning of care in a feminine space, reminding readers of the ideal and ethical meaning of care that can include the act of taking responsibility for one's mind. Thus, Tom's life is more heroic, as he embodies both the values of human culture and the spirit of salvation. Tom conveys the aesthetic meaning of care, based on emotional abilities, such as true empathy and altruism, by showing that care should not be restricted as a female responsibility.

\section{Conclusion}

Since the 1920s, there has been an alternative reading of Cather's literary importance; one that sees her work as exemplary of the power of art to evoke universal values (Wilson, 2005, p. 62). Even though Cather herself admitted that "the novel was gloomy and not her favorite" (Stout, 2002, p. 119), it is valuable for its depiction of care ethics, as well as for its considerable attention to care values. Cather emphasizes the importance of different moral values through her depiction of marginalized figures such as Augusta, Mother Eve, and Tom. In the novel, the male protagonist, St. Peter, is initially depicted as a weak individual lacking self-esteem and feeling oppressed by his family; he wants nothing more than to stay in his study in an old house and remember his glory days. This shows the direction in which the novel should be interpreted, by keeping in mind the concept of care. In the novel, Cather shows that the spirit of feminist and feminine care can ultimately realize the value of consciousness of the healthy community, as well as foster the spirit of reciprocal care. Thus, female-based caring communities, care societies, and care networks can be more effective in embodying futuristic visions for general well-being and a healthy life, compared with male-centered care communities that are mired in privileged irresponsibility. This is how St. Peter ultimately realizes the meaning of his life through Augusta's feminine care and care ethics, which allows his body, mind, and soul to find harmony.

Care ethics is such an ordinary concept that its deep implications are often overlooked. However, Cather knew that life could be destroyed without proper care related to emotional responsibilities: "caring, good caring, seems not only to involve overt actions but also an attitude, a sentiment, or an emotion that accompanies behavior" (Kittay, 2002, p. 244). Thus, the care shown in the novel does not stem from a superficial sense of duty, but is rather a sincere act engendered by the trust between individuals; it delivers the message that all beings are interdependent and caring can make life a good life. Further, Eva Kittay emphasizes that caring as labor of love is based on holding "another's well-being as a primary responsibility and a primary good" (2002, p. 241). In this sense, all the major characters mentioned in the essay show a spirit of self-sacrifice aimed toward the development of a caring society, devoid of gendered limitations. Therefore, care can be a solid duty established on an ethical basis.

In the current era of disaster, care can be an act of love exchanged between individuals. Virginia Held insists that "to be a caring person requires more than the right virtues or dispositions. It requires the ability to engage in the practice of care, and the exercise of this ability" (2006, p. 51), emphasizing the importance of practicing care. This suggests that it is time for us to implement the ethical aesthetics of practical and acting care. This is because the ethical aesthetics that harmonize with the human mind's abilities contribute to the completion of care and emphasize the perception of one's surroundings through emotional capabilities. This practice, which can change the way people view care practice globally, can contribute to forming 
a virtuous cycle of care in society not only by promoting personal growth but also by stimulating the likelihood for better care.

\section{References}

Baker, A. (2010). Terrible women: Gender, Platonism, and Christianity in Willa Cather's The Professor's House. Western American Literature, 45(3), 253-274.

Bowden, P. (1997). Caring: Gender Sensitive Ethics. New York: Routledge.

Cather, W. (1990). The Professor's House. New York: Vintage Books.

Cather, W. (with Tennant, S.). (1988). Willa Cather on Writing. Lincoln and London: University of Nebraska Press.

Donovan, J. (2016). The Aesthetics of Care: On the Literary Treatment of Animals. New York: Bloomsbury Publishing.

Durrans, S. (2010). The Temptation of St. Peter: Flaubert's Saint Anthony and Cather's The Professor's House. In J. J. Murphy, F. Palleau-Papin, \& R. Thacker (Eds.), Willa Cather: A Writer's World (pp. 176-192). Lincoln and London: University of Nebraska Press.

Engster, D. (2007). The Heart of Justice: Care Ethics and Political Theory. Oxford: Oxford University Press.

Gilbert, S. M. \& Gubar, S. (1989). No Man's Land: The Place of the Woman Writer in the Twentieth Century. New Haven: Yale University Press.

Held, V. (2006). The Ethics of Care: Personal, Political, and Global. Oxford: Oxford University Press.

Kittay, E. (2002). Loves Labor Revisited. Hypatia, 17(3), 237-250. http://dx.doi.org/10.1111/j.15272001.2002.tboo951.X

Kot, P. (2002). Speculation, Tourism, and The Professor's House. Twentieth Century Literature, 48(4), 393-426. http://dx.doi.org/10.2307/3176041

Leddy, M. (1996). 'Distant and Correct': The Double Life and The Professor's House. In S. J. Rosowski (Ed.), Cather Studies 3 (pp. 182-196). Lincoln \& London: University of Nebraska Press.

Lewis, E. (with Murphy, J. J.). (200o). Willa Cather Living: A Personal Record. Lincoln: University of Nebraska Press.

Moseley, A. (2002). The Religious Architecture of The Professor's House and Death Comes for the Archbishop. In J. J. Murphy (Ed.), Willa Cather and the Culture of Belief (pp. 63-80). Provo, Utah: Brigham Young University Press.

Noddings, N. (2012). The Caring Relation in Teaching. Oxford Review of Education, 38(6), 771-781. http://dx.doi.org/10.108o/03054985.2012.745047

Peek, C. A. (2010). Prelude: The Prophetess and the Professor: Rescuing Cather from the Past. In J. J. Murphy, F. Palleau-Papin, \& R. Thacker (Eds.), Willa Cather: A Writer's World (pp. 1-19). Lincoln and London: Nebraska University Press.

Perriman, W. K. (2006). Cather's Literary Choreography: The 'Glittering Idea' of Scientific Warfare in The Professor's House. In S. Trout (Ed.), History, Memory, and War (pp. 244-27o). Lincoln \& London: Nebraska University Press.

Rabin, J. G. (2004). Surviving the Crossing: (Im)migration, Ethnicity, and Gender in Willa Cather, Gertrude Stein, and Nella Lason. New York: Routledge.

Rosowski, S. J. (2003). The Comic Form of Cather's Art: An Ecocritical Reading. In S. J. Rosowski (Ed.), Willa Cather's Ecological Imagination: Cather Studies 5 (pp. 103-127). Lincoln \& London: Nebraska University Press.

Ruddick, S. (1998). Care as Labor and Relationship. In J. C. Haber \& M. S. Halfon (Eds.), Norms and 
Values: Essays on the Work of Virginia Held (pp. 3-25). MD: Rowman \& Littlefield.

Stout, J. P. (2002). A Calendar of the Letters of Willa Cather. Lincoln and London: Nebraska University Press.

Tong, R. (2018). Feminist Thought, Student Economy Edition: A More Comprehensive Introduction. New York: Routledge.

Tronto, J. C. (1993). Moral Boundaries: A Political Argument for an Ethic of Care. New York: Routledge.

Wagers, K. (2015). Against the American Grain: Willa Cather's History Troubles. Texas Studies in Literature and Language, 57(1), 106-127. http://dx.doi.org/10.756o/TSLL57105

Wilson, A. (2005). Canonical Relations: Willa Cather, America, and The Professor's House. Texas Studies in Literature and Language, 47(1), 61-74. http://dx.doi.org/10.1353/tsl.2005.0008

Dr. Hyojeong Byun is currently an Associate Professor of College of Creative Future Talent, Daejin Juniversity, Pocheon-si, South Korea. Her research concentrates on modern American novels, literary theories, and comparative literature studies and so on. She has written nineteen $\mathrm{KCI}$ articles since 2013, which have been published in South Korea and she has earned a research fund from National Research Foundation of Korea before. 